\title{
„TENNI VAGY NEM TENNI” - A MAGYAR AZONNALI FIZETÉSI PROJEKT NÉHÁNY TAPASZTALATA ${ }^{1}$
}

\author{
Czímer József - Kiszely Róbert ${ }^{2}$
}

2008, a brit Faster Payments System bevezetése volt a nyitánya a modern azonnali fizetési rendszerek korszakának. Azóta több mint ötven országban vezették be ezt a szolgáltatást, olyan eredményesen, hogy az azonnali fizetési rendszer a pénzforgalmi szolgáltatások normájává vált. Az új országok száma hónapról hónapra növekszik, ugyanakkor a fejlesztés hangsúlya áttevődik inkább a meglevő rendszerek interkonnektivitásának megteremtésére és a határokon átívelö, azonnali fizetési szolgáltatások létrehozására.

Magyarország mindig innovatív volt, a külföldi turisták például már 1961-ben tudtak bankkártyával fizetni az országban. Nem meglepő éppen ezért a Magyar Nemzeti Bank előremutató döntése az azonnali fizetési szolgáltatás Magyarországon történő bevezetéséről. A döntéstől számítva kicsit több mint három évvel később megindult az országban az azonnali fizetési szolgáltatás, amely forintban denominált azonnali fizetéseket kezdett ajánlani az ügyfeleknek. A Capsys Informatikai Kft. hangsúlyos müszaki szereplője volt ennek a folyamatnak. Ebben a cikkben visszatekintünk az implementáció folyamatára, és az akkor szerzett tapasztalatainkat osztjuk meg az olvasókkal.

JEL-kódok: $\mathrm{E}_{42}, \mathrm{O}_{32}$

Kulcsszavak: azonnali fizetés, implementáció, tesztelés, tanulságok, Capsys

1 A cikk első alkalommal a Journal of Digital Banking Henry Stewart Publications LLP (United Kingdom) folyóiratban jelent meg angol nyelven. RóBert Kiszely - Jozsef Czimer (2020): Do's and don'ts of immediate payments implementation: The Hungarian story. Journal of Digital Banking 5(2), 1-9.

2 Czímer József London Office vezető, Capsys Informatikai Kft. E-mail: jozsef.czimer@capsys.hu. Kiszely Róbert igazgató, Professional Services, Capsys Informatikai Kft. E-mail: robert.kiszely@ capsys.hu. 


\section{BEVEZETÉs}

2020. március 2. nagy nap volt a magyar pénzügyi szolgáltatások életében: pontosan éjfélkor elindult a szolgáltatás a Giro Zrt. által üzemeltetett, azonnali fizetési központi infrastruktúrán, amely lehetővé teszi, hogy a pénzforgalmi szolgáltatók ezen az infrastruktúrán indíthassanak tranzakciókat ügyfeleik megbízásából.

Ez a nap valóban nagy nap volt azért is, mert a magyar rendszer nagyon sok aspektusában eltér a világon másutt bevezetett azonnali fizetési rendszerektől. A legnagyobb különbség a Magyar Nemzeti Bank által megadott keretrendszerben rejlik, amely a projektet is meghatározta. A szolgáltatásnak az MNB által meghatározott, főbb jellemzői a következők:

- az MNB rendelkezése szerint a Giro Zrt. által üzemeltetett azonnali fizetési infrastruktúra használata kötelezően előírt minden magyarországi pénzforgalmi szolgáltatói jogosultsággal rendelkező szolgáltató részére;

- minden átutalási megbízást az azonnali infrastruktúra felhasználásával kell indítani, amely

- a megbízó HUF számlája terhére lett indítva;

- összege nem haladja meg a tízmillió forintot;

- elektronikusan lett elindítva;

- nem tartalmaz konkrét értéknapot;

- nem kötegelt utalásokat tartalmazó vállalati transzfer;

- a meghatározott tranzakciós idő öt másodperc;

- a rendszer már működése kezdetétől biztosítja a fizetési kérelem típusú ügylet lehetőségét;

- a rendszer a következő másodlagos azonosító alkalmazásának lehetőségének biztosítja:

- mobiltelefon-számok;

- e-mail-címek;

- adóazonosítók/adószámok;

- az üzenetek meghatározott szabványa az ISO 20022;

- a rendszer a Giro Zrt. által kiadott HCT Inst Szabálykönyv elöírásai szerint működik.

A projekt komplex jellege miatt mintegy 3500 szakember dolgozott annak megvalósításán közvetlenül, nem számítva a szállító cégek szakembereit és a bankok kimondottan pénzügyi termékekért felelős dolgozóit. A Capsys Kft. jelentős résztvevője volt a projektnek, miután a legjelentősebb piaci szereplők közül kettőnek 
partnere is volt. A rendszerek jelentőségét mutatja, hogy ez a két csoport érintett a magyarországi fizetési forgalom volumenének mintegy kétharmadában.

Jelen cikkben szeretnénk némileg bennfentes képet adni a projekt lefolyásáról, illetve szeretnénk megosztani ezen nagyon komplex, de sikeres projekt során szerzett tapasztalatainkat.

\section{A projekt időtartama}

Ahhoz, hogy több mint harminc szervezet egy ilyen összetett projektet közösen lebonyolítson, idő szükséges. Nagyon nehéz előre meghatározni pontosan, hogy mennyi, de minden nemzetközi tapasztalat is azt mutatja, hogy nagyon fontos a megfelelő időtartam biztosítása!

MNB-igazgatósági döntés az azonnali fizetési infrastruktúra létrehozataláról

2017. JÚLIUS

Az önkéntes teszt megkezdése

2019. ÁPRILIS

Pilotteszt az élő rendszerek részére

2019. JÚLIUS 1.

Teszt az élő központi infrastruktúrán; 2019. SZEPTEMBERTŐL kötelező teszt

2020. MÁRCIUS 2.
MNB Pénzügyi Stabilitási Tanács döntése a projekt elindításáról

2017. MÁRCIUS

A nemzeti szintű projekt elindul, az időtervet meghirdették

2019. JANUÁR

A kötelező tesztidőszak elkezdődik

2019. JÚNIUS

AZ INDULÁS TERVEZETT NAPJA

2019. JÚLIUS

ÁTTERVEZETT INDULÁSI IDŐPONT 
A Magyar Nemzeti Bank hivatalos közleménye az azonnali fizetési szolgáltatás modelljéről és az ehhez szükséges infrastruktúra létrehozásáról 2016. december 14-én jelent meg. ${ }^{3}$ A témáról szóló belső beszélgetések az MNB-ben már 2013ban megkezdődtek. A hivatalos döntés magas szinten, a Pénzügyi Stabilitási Tanácsban született, amely később folyamatosan figyelemmel követte a projektet, amelynek a befejezését 2019. július 1-re tervezték. Az MNB talán minden idők legbölcsebb döntését hozta meg - legalábbis a pénzforgalom területén - akkor, amikor később, felismerve a projekt lebonyolításának valóságos helyzetét és lehetőségeit, nyolc hónappal elhalasztotta az azonnali fizetési infrastruktúra elindítását, kötelezve egyben a résztvevőket arra, hogy az így keletkezett többletidőszakot kötelező teszteléssel töltsék el.

Pénzforgalmi szolgáltatói oldalon az OTP Bank 2018. április 11-én ${ }^{4}$, a Takarékinfo pedig 2019. január 29-én ${ }^{5}$ jelentette be a projektben való részvételét.

A közlemények kiadásának időpontja is mutatja, milyen sok idő kellett a tervezéshez és a megfelelő hatékonyságú döntés meghozatalához. A Capsys komoly szerepet kapott a legnagyobb magyar közvetlen banki projektek közül kettőnek a lebonyolításában. A projektek tartalma nem pontosan ugyanaz volt, de mindkettő alapján szerzett tapasztalatainkat ebben a cikkben foglaljuk össze.

\section{Az ördög a részletekben rejlik}

A kijelentés magától értetődőnek tűnhet, de aláhúzandó, hogy az azonnali fizetési rendszer alapvetően technológiafüggő megoldás. A pénzforgalmi szolgáltatók természetesen már régóta tudták, hogyan kell a fizetéseket elszámolni - klíringelni, vagy egy régies szóval zsirálni -, de sokáig az akkor létező technológia nem tette lehetővé, hogy ezek a folyamatok gyorsabban bonyolódhassanak le. Az igazi gyorsaság a bankkártya-technológiák elterjedésével honosodott meg, de sem a meglevő hardverek, sem pedig az uralkodó ISO 8353 üzenetszabvány nem tette lehetővé olyan adattartalmú üzenetek küldését, amelyek egy átutalást teljes tartalmában kezelni tudtak volna. Érdekes módon az online fogadás, az online játék iparág harcolta ki magának azt a technológiai megoldást, amelyet később a pénzforgalmi szolgáltatások is átvettek az azonnali fizetési rendszer létrehozásához.

3 https://www.mnb.hu/letoltes/az-mnb-dontesevel-uj-korszakba-lep-a-digitalizacio-a-hazaipenzugyi-szektorban.pdf.

4 https://www.finextra.com/pressarticle/73421/hungarys-otp-bank-turns-to-aci-worldwide-forinstant-payments.

5 https://www.fintechfutures.com/2019/o1/aci-worldwide-to-power-hungarian-real-timepayments/. 
Ahhoz, hogy egy számítástechnikai rendszer másodpercenként pénzügyi átutalások százait, vagy egyes rendszerek esetében ezreit az egyik számláról a másik számlára továbbítani tudja, egyrészt nagyon robusztus hardverrendszer, másrészt nagyon részletes, jól kidolgozott és folyamatosan monitorozott szoftvermegoldás szükséges. Természetesen minden technológiai megoldás hordoz valamennyi kockázatot, de az átutalásnak időben el kell jutnia a kedvezményezetthez, ezt a rendszernek biztosítania kell. Az azonnali fizetési technológia nagyon szenzitív, a legkisebb hiba vagy rossz konfiguráció hibás tranzakciót eredményezhet. Láthattuk, mi történik akkor, amikor a küldő és a fogadó rendszerek time-out beállításai nem azonosak: tranzakciók vesznek el. A magyar projektben részt vevő szakembereknek csak nagyon kicsi része rendelkezett korábbi gyakorlattal ezen a területen, így a projekt keretében megtanulhattuk:

Tanulság: minden részlet számít!

\section{A „forró” témák Magyarországon}

Minden projekt lebonyolítása során vannak olyan területek, amelyek valamilyen okból sokkal nagyobb figyelmet keltenek, mint más, szintén fontosnak tűnő témák. Ilyen „forrónak” nevezett témák a magyar projektben is voltak. Sok esetben a projekt résztvevői rengeteget pörögtek, forogtak a probléma körül, lassan haladt a kérdés megoldása. Ezek a problémák ugyanakkor nagyon fontosak, a viták pedig gyümölcsözőek voltak abból a szempontból, hogy megértsük a probléma lényegét, hogy valamiféle egyetértés alakuljon ki azok megoldásához.

\section{- A nagy TPS-kérdés - hány tranzakció menjen másodpercenként?}

Az elindított tranzakciónak öt másodperc alatt el kell érnie a kedvezményezett számláját. ${ }^{6}$ Ez a megállapítás a szabályozó részéről egyszerü jogi kérdés volt, ugyanakkor a pénzforgalmi szolgáltatóknak a rendszereiket ennek az elöírásnak megfelelően kellett felépíteniük. Mindenkinek ezen előírás alapján kellett meghatároznia saját rendszerének a kapacitását, azaz általános megközelítésben egy nagybank rendszerének nagy TPS (trasaction per second - tranzakció másodpercenként) kapacitással kell rendelkeznie, míg egy kisbanknak alacsonyabb kapacitás is elegendő lehet. Ahhoz például, hogy a rendszer egy perc alatt feldolgozzon két tranzakciót, 1 TPS - ami 60 tranzakciót jelent egy perc alatt - névleges kapacitás elégnek tünik, de mi történik akkor, ha egy nagybank öt tranzakciót is elindít egy másodperc alatt egy kisbank ügyfeleinek

6 A szabályozás értelmében a fogadó bank számláján kell 5 másodpercen belül a jóváírásnak megtörténnie, ez azonban a kedvezményezett ügyfél számláján történő jóváírással lényegében azonos. 
címezve, vagy akár a kisbank ügyfelei közül többen is ugyanakkor akarnak tranzakciót indítani? Egy ilyen helyzet rendszerproblémákat okozhat, vagy lelassíthatja a tranzakció feldolgozását, ugyanakkor nem létezett olyan szabályozás, amely meghatározta volna a minimumszintet a bankok számára. A korábbi kötegalapú rendszerek statisztikáiból kiindulni nagyon nehéz, és szinte lehetetlen az egy óra alatt lebonyolított tranzakciók számát másodperce lerövidítve hatékonyan interpolálni. A tapasztalat végül is azt mutatta, hogy a félelmek túlzóak voltak, a tervezett TPS-értékek jóval magasabbak voltak, mint a valós gyakorlati igény, legalábbis eddig...

\section{- Az elveszett üzenetek kérdése}

Ahogy az az implementációs projektek lebonyolítása során szokásos, a tesztelés már a munka korai fázisában elkezdődött, és folyamatosan egyre fontosabbá vált. Ezalatt a bankok azt is tapasztalhatták, hogy üzenetek - és ennek alapján tranzakciók - egyszerűen elvesztek. Nagyon sok közös tesztelés, próba után és során a Giro és a résztvevő bankok is számtalan módosítást hajtottak végre a rendszeren egészen addig, amíg az elveszett üzenetek száma elfogadhatóvá nem vált. A mai szint végül is „vállalható”, de a technológiának biztosítania kellene a zéró szintü üzenetvesztést még kisebb üzemzavar esetén, például hálózati kapcsolat szakadása esetén is.

\section{- Elektronikus aláírás}

Az országos projekt során a központi infrastruktúra és az ahhoz kapcsolódó banki projektek lényegében párhuzamosan futottak. Így a legapróbb (és mint fent írtuk, implementáció szempontjából lényeges) részletek a projekt során tisztázódtak. Ilyen részlet volt az üzenetek elektronikus aláírása. Egy ilyen részlet megvalósítása a központi infrastruktúra szempontjából apróságnak tünhet, de elöfordulhat, hogy banki oldalon több hónapnyi kifutása van. Ezért fontos (és jó gyakorlatnak bizonyult) egy országos projekt keretében az ütemezés kapcsán bizonyos rugalmasság: az ehhez hasonló, nem kritikus követelmények első körben nem kötelezőek, a tesztelések megkezdődhetnek nélkülük, így összességében nem okoznak jelentőst csúszást a projektben.

\section{- Köteg vagy nem köteg?}

A fentiekben beszéltünk a TPS-kérdésről, amelynek az egyik megoldása: átmenetileg a Magyar Nemzeti Bank nem engedélyezi azt, hogy a bankok a vállalati kötegben rögzített utalásokat az azonnali fizetési rendszerbe küldjenek. Egy-egy köteg jelentős számú tranzakcióval terhelné a rendszert, ezért a kötegküldés lehetősége csak 2020. szeptember 1-je után fog a bankok rendelkezésére állni, addig a rendszer valószínüsíthetően stabilizálódik. A kérdés 
megoldását jelentheti az is, hogy a kötegüzeneteket a bankok csak korlátozott sebességgel küldhetik úgy, hogy az persze így is azonnali tranzakciót eredményez.

- Fogadóoldali időtúllépés - „Creditor time-out” (ABo5)

A projekt - és általában az azonnali fizetés - egyik nagy mumusa! A tesztelés alatt ez lett a sátán maga - az számított hibapontnak, ha fogadó bankként jelentkezett. Ez az üzenet azt jelenti, hogy a tranzakciót fogadó bank nem válaszolt időben. Ennek számos oka lehet, például egyszerű üzenetvesztés. Előfordulhat ugyanakkor az is, hogy a sajátos time-out szabályok miatt a központi rendszer összesen o,1 másodpercet ad a fogadó banknak a feldolgozásra, amelyiknek így nincs ideje válaszolni. Elképzelhető, hogy ez az eset nem is a fogadó bank hibája, bár akként jelentkezik - csak ezt be is kell bizonyítani. Az ügyfél szempontjából ugyanakkor ez nagyon rossz, mivel a 20 másodpercig tartó feldolgozás után a tranzakció mégis elutasítással végződik. Mindezek ellenére a rendszer végül is sikeresen vizsgázott, hiszen az első két és fél nap alatt több mint egymillió tranzakciót dolgozott fel 150 milliárd forint értékben? Idővel a time-out szabályokat érdemes statisztikai alapokon felülvizsgálni az időtúllépési szabályok ugyanis nem garantálják a rövid tranzakciólefutást, csak biztonsági szelepként funkcionálnak.

\section{- Egyeztetések - reconciliation report}

A hiba nélküli működésnek bármely azonnali fizetési rendszer természetes jellemzőjének kell lennie. Ennek biztosításához - nem a müszaki oldalra gondolunk - eszközre is szükség van. A projekt első szakaszában úgy tűnhet, hogy a rekonciliáció csak egy a számos jelentés között. Úgy a Giro, mint a pénzintézetek nagyon sokat dolgoztak azon, hogy a rekonciliáció jól, hatékonyan működjön. Egy jól működő rekonciliációs rendszerben ugyanis még az elveszett(nek hitt) üzenetek is megtalálhatók, mivel e rendszer a rekonciliációs jelentést óránként előállítja. Érdekesnek tűnhet, hogy egy azonnali átutalási rendszerben nem azonnal kutatnak fel egy elveszett üzenetet, de éppen a rendszer használatának kötelező volta miatt nem tünik fel minden ügyfélnek az, hogy az utalás nem ért célba öt másodpercen belül. Ne felejtsük el ugyanis, hogy Magyarországon az azonnali fizetési rendszer az óránként utalást váltotta ki kötelezően, így az induláskor az ügyfelek nem mindegyike tudja, hogy utalásának azonnal célba kellett volna érnie, így ezt nem is várja el, nem fog azonnal reklamációt indítani. Továbbá egy adott bank döntése, hogy dolgoznak-e operációs munkatársai $7 \times 24$ órában, lehetővé téve az azonnali beavat-

7 https://www.giro.hu/kozlemenyek--/sikeresen-vizsgazik-az-azonnali-fizetes-infrastrukturaja. 
kozásokat minden nap minden pillanatában, hiszen ennek a költsége nagyon magas az adott órai tranzakciószámhoz viszonyítva.

- A pilotprojekt kérdése

A Magyar Nemzeti Bank eredeti terve egy „big bang” jellegű indulás volt 2019. július 1-jén. Az általunk ismert, előzetes nemzetközi tapasztalat azt mutatta ugyanakkor, hogy a felkészülési idő rövid lehet, és ez be is bizonyosodott. A pénzintézetek komoly lobbitevékenységet fejtettek ki a kérdésben. A kialakult helyzetet felmérve, a Nemzeti Bank végül nagyon jó döntést hozott egy további nyolc hónapos, de kötelező pilotidőszak beiktatásával. Ez alatt az időszak alatt a bankok nagyon nagyszámú átutalást indítottak, ugyanakkor csak kevés technikai számlát használtak a teszteléshez. Valóban sok problémát sikerült felderíteni ebben az időszakban, de maga az a tény, hogy a teszteléshez használt számlák nem valódiak, hanem technikaiak voltak, további problémát okozott később. Mindezek ellenére a projekt indulása sikeres volt!

Tanulság: folyamatos országos szintü egyeztetések szükségesek!

\section{Minden jó, ha a vége jó...}

A tervezés során mindenki hibamentes, jó projektet tervez, az implementáció is ezzel a gondolattal kezdődik. A projekt során ezt neveztük „happy path”-nak, szabad fordításban „szerencsés lefutás”-nak. A hibák, esetleg tervezési tévedések kezelése jóval nehezebb dolog, ezeket elöre teljes körben elképzelni, megtervezni nagyon bonyolult, de nem is biztos, hogy szükséges. A tesztelés az az időszak, amikor jó esetben a hibákra fény derül. Ritka ugyanakkor, hogy a tesztelés első próbálkozásra simán menjen. Ekkor derül ki, hogy a fejlesztésben, implementációban résztvevők melyik szabványt értelmezték éppen különféleképpen, mit nem sikerült megfelelően implementálni, mi volt a különbség a Giro és a bankok értelmezése között. Jellemző például, hogy a központi rendszer egy üzenetet viszszautasít akkor is, ha maga az üzenet üzletileg korrekt volt, de technikailag hibás. Amennyiben a bank nem készül fel előre a visszautasításokra, mert a „jó megoldást” implementálta elöször, akkor nagyon nehéz ezeket a kezdeti tesztelés során tipikusan felmerülő hibákat felismerni és kijavítani. Fontos, hogy a résztvevők azonosan értelmezzék a dolgokat, de a tesztidőszak nagyon jó lehetőséget biztosít a hibák, félreértések kijavítására, persze jó együttműködés esetén. El kell tehát érni, hogy senki se mondhassa: elküldtem az üzenetet, csak az nem ért oda...

Tanulság: elsö naptól készüljünk a meglepetésekre, könnyebb lesz a hibák kijavítása! 


\section{„Hosszú távon mindnyájan halottak vagyunk”}

Ez a keynesi idézet sokszor elhangzott a projekt során. A tervezés során a fő célunk egy időtálló megoldás létrehozása. A rendszertervező csapat ilyenkor azt a gyakorlatot is követheti, hogy minden ismert és korszerü megoldást betervez a rendszerbe, de ez a gyakorlat a következő gondokat eredményezheti:

- a tervezési időszak nagyon elhúzódhat, és ez a megközelítés elterelheti a figyelmet a szigorúan vett megfelelés szempontból fontos részletekről;

- az így megtervezett rendszer hatékonysága alacsony lehet, mivel jó néhány olyan funkcióval fog rendelkezni, amelyet a gyakorlatban még sokáig nem tudnak hasznosítani;

- a költségek túl magasak lehetnek;

- a tervező fejében levő termékek közül néhány elképzelhető, hogy nincs is a bank terméklistáján, illetve a folyamatai között, amelyek támogatása ugyanakkor a rendszer feladata lenne.

A fenti tapasztalások alapján a projektet két részre kell bontani: az első egy megfelelöségi - compliance - rész, amelynek a célja a létező valós elvárásoknak, szabályoknak és határidőknek való szigorú megfelelés, a második pedig az innovációs rész, amely során az álmokat is meg lehet valósítani, és nem szorít annyira a határidő. Ez természetesen nem azt jelenti, hogy a megfelelöségi résznek nem egy világos, időtálló megoldást kell eredményeznie, hiszen a specifikus compliance követelményeknek, megoldásoknak is hosszú távra kell születniük!

\section{Tanulság: két projektszint legyen - compliance és innováció.}

\section{Ugyanaz, ugyanaz, de mégsem}

A projekt során megtapasztaltuk, hogy még az egyértelmünek tünő szabványok sem mindig egyértelműek. Szinte minden esetben számos egyeztetés volt arról, hogy a Giro alkalmazta-e megfelelően az adott elöírást, vagy pedig a bankoldali implementáció volt a jó. Sajnos, ezek az eltérések általában már csak akkor derültek ki, amikor az adott bank csatlakozott a Giro rendszeréhez.

Ez a legdrágább gyakorlat, mert a fejlesztési, implementációs folyamat így a következő: a szállító termékfejlesztési csapata elkészíti a központi rendszer-

8 „In the long run we are all dead.” In Keynes, J. M. (1923): The Tract on Monetary Reform. London: Macmillan and Co., limited. 
dokumentáció szerint a fejlesztést, és teszteli azt. Utánuk következik a szállító projektcsapata, amelyik beépíti az ügyfélspecifikus implementációt, majd következik az ő tesztelésük. Ök adják át az így elkészült anyagot az ügyfélnek, aki ezt egy „landing” környezetbe telepíti és maga is teszteli, majd felteszi a központi rendszerhez integrált környezetre. A probléma végül is csak itt derül ki, ezért a javításnak a teljes láncolaton újra végig kell mennie. Amennyiben létezik olyan teszteszköz, amelyik a központi rendszert szimulálja, akkor a hiba már sokkal korábban, a szállító termékfejlesztési csapatánál is kiderülhet, ami rengeteg idő és költség megtakarítását eredményezi. A müszaki dokumentációk nagyon fontosak, de nem tartalmaznak minden apró részletet, és mint tudjuk: az ördög a részletekben rejlik. Sok ilyen kis ördöggel találkoztunk az implementáció során: az ISO 20022, SOAP-, XML-, TCP-szabványok értelmezésének különbségei számos gondot okoztak.

\section{Tanulság: a központi infrastruktúra szolgáltatójának minden üzenettípushoz a lehetö legrészletesebb szimulációs példákat kell biztosítania.}

\section{Fejlesztő kontra közlemény}

Ez most csak egy tréfa, de a projekt során valóban voltak humorosnak szánt pillanatok is, amikor például a közlemény rovatba írtak a kollegák humoros dolgokat. Botrány persze nem lett belőle, csak egy kis dorgálás - emiatt senki sem vesztette el az állását!

\section{Tanulság: ne engedd a fejlesztödnek, hogy a közleményt kitöltse ...}

\section{Kötegek, valamint a nagy TPS-kapacitású feldolgozás}

Ezt a témát a fentiekben már a „forró” témák tárgyalásakor érintettük. Vissza kell még egyszer térni ehhez, mivel a tapasztalatok azt mutatják, hogy ez kiemelkedően fontos kérdés. Ugyanakkor a magyar projekt egyik különleges sajátossága, nevezetesen az, hogy minden piaci résztvevőnek kötelező volt benne részt vennie, minden kérdést még fontosabbá tett.

Az országos projekt meghatározta, hogy a központi rendszer kapacitása legalább 500 TPS (tranzakció per secundum) legyen, ugyanakkor semmilyen iránymutatást nem adott ara vonatkozólag, hogy az egyes bankok rendszereinek mekkora kapacitással kell rendelkezniük. Egy bankkártyarendszer esetében a kibocsájtani tervezett kártyák és/vagy a kártya-elfogadóhelyek száma alapján jól meg lehet határozni a kapacitásszükségletet, de egy azonnali fizetési rendszerben ez nincs 
így. A kapacitás tervezése ugyanakkor nagyon fontos, mert ez határozza meg a költségeket is, ami az azonnali rendszerek esetében nem kevés. Az is nehezíti a kérdést, hogy egy banknál lehet ugyan kevés számla, például az alapvetően a vállalatok részére szolgáltató bankok esetében, de egyes ügyfelek, mint például a nagy szolgáltatóvállalatok, nagyon sok átutalást kaphatnak rövid idő alatt. Az utalások időbeli koncentrációjának az előrejelzése nem könnyü, főleg egy olyan rendszer esetében, mint a magyar, ahol a pénzintézetek tapasztalati számokkal még nem rendelkeznek. A szolgáltatás indulása után ugyanakkor azt mondhatjuk, hogy komoly méretezési hibák nem történtek, ami esetleg becsúszott, azt könnyen lehet korrigálni.

\section{Tanulságok: a kapacitásokat elöre egyeztetni kell, illetve létre kell hozni a kötegelt fizetések elkülönítési mechanizmusát is.}

\section{„Zsiráfolás” technika}

A hazai azonnali fizetési rendszer egyik sajátossága, egyben nehézsége is volt, hogy egy időben több mint harminc pénzforgalmi szolgáltatónak kellett kialakítania a saját rendszerét; egy ilyen nagyságrendű projekthez ugyanakkor kevés olyan szakember állt rendelkezésre, aki korábban bármikor is foglalkozott volna akár hasonló rendszerrel is. Van néhány nagyon jó számítástechnikai cég Magyarországon, de korábban egy sem vitt végig azonnali fizetési rendszerrel kapcsolatos bevezetési projektet, mint ahogy csak kevés olyan szakember volt, aki személyesen részt vett volna azonnali fizetés projektben. A Capsys abban a szerencsés helyzetben volt, hogy a projektek indulásakor rendelkezett már ilyen tapasztalattal.

A fenti okok miatt a tudásmegosztás a projekt egyik legfontosabb elemévé vált, annak egyik legjobb technikáját pedig „zsiráfolás” névvel illettük. Ez azt jelenti, hogy a tapasztalt munkatárs ül a számítógépénél és dolgozik, míg kevésbé tapasztalt kollégái állnak mögötte, és nézik a válla fölött a képernyőt, azaz zsiráfolnak. Ez a kialakult, nagyon hasznos technika a folyamat első része, később a kevésbé tapasztalt kolléga végzi a gépnél a munkát, tapasztaltabb társa pedig zsiráfolva ellenőrzi őt.

Tanulság: a projekt elsö pillanatától kezdve széleskörü tudástranszfer szükséges! 


\section{Mennyi tesztelés kell?}

$\mathrm{Az}$ országos projekt tervezésekor az ütemezés a következő volt: két hónap Connectivity test (technikai kapcsolódási teszt) és öt hónap Certification Test (az egyes csatlakozó tagok „bizonyítványa”, hogy felkészültek az azonnali fizetési rendszer elindítására), azaz összesen hét hónap tesztelés került a tervbe. Egy hasonló banki infrastruktúra projektsorán az alábbi teszteléseket kell végrehajtani:

- Unit Test - a szállító fejlesztője végzi a saját környezetén;

- Integration Test - a szállító végzi a saját környezetén;

- Smoke Test - a bank környezetén történik az egyes „dobozok” tesztje különkülön, azért, hogy ellenőrizzék, rendben van-e a szállítás;

- Connectivity Test - a bank környezetén történik azért, hogy megállapítsák, egyes „dobozok” tudnak-e kommunikálni egymással;

- System Integration Test - end-to-end tesztelés annak megállapítására, hogy az egyes folyamatok végigmennek-e a rendszereken;

- User Acceptance Test - a banki üzleti tesztelők részletes tesztelése annak megállapítására, hogy minden funkció, minden valós adatkombináció helyesen (az elvártaknak megfelelően) müködik-e;

- Load Test - várható nagy terhelés melletti teszt;

- Stress test - extrém nagy terhelés melletti teszt;

- Disaster Recovery Test, High Availability Test - haváriahelyzetek tesztelése.

A fenti tesztperiódusok a projekt során többször is újra meg újra sorra kerülnek, egyrészt azért, mert olyan projekt nincs, amelynek során minden elsőre jó lesz, illetve például egy hibás eredményű Load Test utáni javítások ellenőrzésére az egész folyamatot meg kell ismételni. A visszatérő tesztek sokszori szükségessége gondokat is okozhat, ha csak egy integrált tesztkörnyezet állít rendelkezésre - az ugyanis alapszabály, hogy élesben nem tesztelünk, kivéve, ha az MNB előírja... Így aztán igen nagy volt a tolongás a tesztrendszeren; egyazon bankon belül számos különböző tesztet akartak egy időben végrehajtani az egyes területek. Egy lehetséges megoldás erre a problémára, ha a központi infrastruktúra szimulátorokat bocsát a csatlakozó tagok rendelkezésére, így nem csak a központi rendszerhez csatlakozva lehet teszteket folytatni.

Az országos projektben a Nemzeti Bank felismerte, hogy a rendszerek még nincsenek készen, és a résztvevőkkel együtt egy nyolc hónapos kiegészítő tesztperiódusban állapodtak meg. Így a tesztelési időszak a korábbi hét hónappal együtt elegendőnek bizonyult, és nagyban hozzásegített ahhoz, hogy stabil, jól működő központi infrastruktúra szülessen, amelyhez jó banki rendszerek csatlakoztak. 


\title{
Tanulság: nagyon sok tesztelés szükséges (9+ hónap), de a valóság sosem szimulálható pontosan, ezért egy fokozatos próbaüzem is szükséges
}

\section{Kedvenc sportja: beleugrani a döntésekbe}

Egy azonnali fizetési rendszer nagyon összetett, bonyolult - föleg akkor, ha az egy „Open banking” ( $\mathrm{PSD}_{2}$ ) megoldással párosul, vagy pedig több felhasználó használ megosztott üzemmódban egy rendszert. Egy ilyen rendszer implementációs folyamata nagyon sok összetevőből áll, olyanokból, amelyek egymásra épülnek, függenek egymástól. Ha az egyik komponensnél jelentkezik egy hiba, az valószínűleg gondot okoz egy másik komponensnél is. Sok esetben előfordul: ahelyett, hogy a közremüködők a hibák gyökerét tárnák fel, gyors megoldásokkal próbálkoznak, ráadásul nem megfelelö információk birtokában. Egy tipikus példa, amikor két rendszer áll kapcsolatban egymással, az $A$ rendszer üzenetet küld a $B$ rendszernek, és vár a válaszra, ami viszont nem érkezik meg. Az a megállapítás, hogy „a $B$ rendszer nem válaszolt”, nem korrekt, mivel több ok is lehetséges: az üzenet elveszett az $A$-tól $B$-ig tartó úton; az üzenet maga hibás volt, ezért $B$ nem tudta feldolgozni; $B$ válaszolt, de az üzenet elveszett; a válasz megérkezett, de $A$ nem tudta feldolgozni stb. Ilyen és ehhez hasonló következtetések miatt a problémák valódi okának keresése gyakran félremehet, esetenként teljesen elakadhat.

\author{
Tanulság: a problémák hatékony megoldásához \\ tényeken alapuló, szigorú logikájú elemzés szükséges.
}

\section{Rekonciliáció}

A projekt elején úgy gondoltuk, hogy a rekonciliáció, az egyeztetés csak formaság, arra kell, hogy kipipáljuk egy feladat végrehajtását. A valóságban ugyanakkor az történt, hogy a tesztelések hangsúlya a nagy volumen kezelésére esett, ami egyébként nagyon eredményesre is sikerült, viszont így néhány speciális eset elveszett a tömegben. A hibás esetek száma valóban nagyon alacsony volt, ugyanakkor szinte minden hiba komolyabb problémát is jelezhet, fel kell tehát deríteni. A rekonciliáció ugyanakkor nagyon jó eszköznek bizonyult az ilyen hibák felderítésében azért, mert a nagy adatmennyiségek elemzése közben a kisebb hibák felderítésére is lehetőséget adott. A későbbiekben a rekonciliáció ezen túl az éles üzemi problémák feltárására is lehetőséget nyújtott.

Tanulság: a tesztelés és a müködtetés támogatására rekonciliációs rendszer beépítése szükséges. 


\section{Szünetmentes üzemeltetés - idő kell hozzá}

A szünetmentes szolgáltatás, $7 \times 24$-ben rendelkezésre állás az egyik legfontosabb jellemzője a modern azonnali fizetési rendszereknek. A teljes architektúra ehhez szükséges fejlesztése nagyon összetett feladat, igen gondosan kell előkészíteni és végrehajtani. Maga az architektúra nemcsak nagyon komplex, hanem ebből kifolyólag költséges is, tehát mindent pontosan, jól kell megszervezni, ami hetek, hónapok munkáját követeli meg. Fontos tehát, hogy szünetmentes üzem elérését tűzzük a zászlónkra, de ennek ára van.

Érdemes figyelembe venni, hogy vannak olyan időszakok, amikor a rendszer terhelése nagyon alacsony, így akár az egész rendszert, akár részeit pár másodpercre le lehet állítani. Néhány tranzakció elutasítása miatt valószínüsíthetően nem lesznek komoly ügyfélpanaszok, főleg ha például ez a leállítás éjszaka történik, ezért már csak biztonsági szempontból is ez a megoldás javasolt. Végül egy kis színes: már a müködés során egy éjjel riasztást váltott ki az, hogy az operátor ötven percig nem látott tranzakciót a rendszeren, gyanakodott! Pedig valóban, ennyi ideig nem volt indított tranzakció.

\section{Tanulság: az elöírásoknak való megfelelés komoly tervezést, sok tesztelést követel meg, és szükséges a költség-haszon elemzés is.}

\section{ZÁRÓGONDOLATOK}

A fent leírtak mutatják, hogy egy, hát még kettő(!) azonnali fizetési rendszer bevezetése nem könnyü dolog. Minden részletnek a helyén kell lennie, még a legkisebb hiba is nagy gondot, esetleg tranzakcióvesztést képes okozni. A rendszernek nagyszámú tranzakció feldolgozására kell képesnek lennie nagyon alacsony hibaszázalék mellett. Egy nemzeti méretű IT-projektnek sokkal komolyabb minőségbiztosítási elemet (tesztelést) kell tartalmaznia, mint egy átlagos projektnek. Az alkalmazott megoldásnak időtállónak kell lennie, ugyanakkor meg kell felelnie a bevezetéskor érvényes elöírásoknak is. Az a tény, hogy mostani digitális korunkban az ügyfelek $7 \times 24$ rendelkezésre állású szolgáltatást várnak el, természetesnek hangzik, de ennek biztosítása a korábbinál komplexebb implementációs és működtetési szolgáltatást követel meg.

A magyarországi projekt egyik legkomolyabb tanulsága az, hogy a teljes körü ügyfélelérési lehetőség biztosítása nem álom, hanem szabályozói döntés kérdése. A magyar bankok sem műszaki-technikai, sem pedig üzletszervezés szempontból nem mondhatók a legfejlettebbeknek, de mindegyik bank sikeresen le tudta bonyolítani ezt az igen komplex projektet. Úgy gondoljuk, hogy ezzel példát mutat- 
tak az Európai Fizetési Kezdeményezést (European Payment Initiative) elindító nagy európai bankoknak, valamint a kezdeményezés támogatóinak, az Európai Bizottságnak és az Európai Központi Banknak, tehát a teljeskörűség elérhető.

Maradt persze végrehajtandó feladat a magyar bankok számára is. Az ország ugyan kicsi, de gazdasága ezer szállal kötődik az Európai Uniónak és a világ többi országának a gazdaságaihoz. Ezt a sokirányú kapcsolatrendszert kell a magyarországi forintalapú fizetési rendszernek is támogatnia azzal, hogy közvetlen digitális kapcsolatot teremt a két páneurópai azonnali fizetési rendszer közül legalább az egyikkel. Miután az EBA Clearing által üzemeltetett RT1-rendszer és az Európai Központi Bank TIPS-rendszere a nyár végére valószínűleg eléri a teljes interoperabilitást, gyakorlatilag mindegy, hogy a magyar fizetési rendszer melyikhez csatlakozik a SWIFT gpi rendszere mellett, amelyik a világ többi országával képes az azonnali fizetési kapcsolatot biztosítani. Végül, de nem utolsó sorban a hazai piacon számos megoldás jelenik meg, amely azonnali fizetésen alapul. A jelenlegi megoldások egyelöre kiforratlanok, mivel nem fedik le a fizetési folyamatokat „faltól falig”, számos alapvető problémával (pl. visszaélés megelőzése) nem foglalkoznak. Egy jövőálló, robusztus fizetési megoldás a piac következő nagy kihívása.

A fizetési szolgáltatások fejlődési folyamata többezer éves, ezért nem fog véget érni azoknak az eredményeknek az elérésével, amelyeket itt bemutattunk. Emellett úgy gondoljuk, hogy az itt bemutatott rendszerek, azokkal a rendszerekkel együtt, amelyeket befejezésben megemlítettünk, sok évig fogják szolgálni a magyar gazdaságot. 